suppression, on the ear and hearing conservation, and lastly on community reaction criteria and the possibilities of legislation.

In a way, noise investigations have progressed. beyond the stage where large scientific break-throughs are to be expected, and the tone of the conference was therefore one of quiet informativeness rather than belligerent assertiveness. Nevertheless, two iterns of interest arose time and time again.

The first concerned units, and the need for the establishment of satisfactory criteria of noise-levels which are in keeping with the true subjective reaction of the community. As one speaker lightheartedly put it, "the reason why acousticians are held in disrepute is because they are still arguing emotionally over units. If electrical engineers still regarded electrical current in terms of the nerve stimulus of a dead frog, they equally would be laughed at". Unfortunately, the subjective unit of noise is "emotional" and must include adequately, though maybe not completely, the stimulus of both the ear and the brain. The conference papers did a great deal to pinpoint these basic parameters ; indeed, the papers by D. W. Robinson and Prof. C. W. Kosten were most satisfactory, not so much for their detailed content, as for the impression conveyed that the corner had been turned, and that provided the scientific manpower was available, units acceptable universally to describe aircraft, motor-cycle and factory noises would be put forward during the next ten years.

The second item which needs airing and which was mentioned by many speakers is the provision of trained acoustical engineers. This has up to now been the prerogative of the university physics departments, and it can only be said that both in Great Britain and elsewhere they have taken this duty lightly, even though in fairness it must be said that there are isolated units fighting against the stream of atomic energy and cosmic research at such universities as Durham (Neweastle upon Tyne), London (Imperial College of Science and Technology), Liverpool and Southampton. However, it is significant that since the death of Prof. E. G. Richardson at Newcastle, there has been no single professor of acoustics in Great Britain, and even with the grandiose plans for university expansion there does not appear to be any rush to put right this deficiency. Even at the Imperial College acoustics appears in a lowly place in the expansion process.

Bearing in mind that physicists are being forced to introduce a greater and greater width of fundamental understanding to their students in the three years at their disposal, it may well be that physies departments are justified in this attitude since the basic physics involved in pure acoustics, if not in noise generation, has been established for many years, and the outstanding problems extend into physiology, psychology and engineering as well as into physies. The time has probably arrived therefore when the custodianship of acoustical training should be taken up by the faculties of applied science or engineering and that such a 'take-over bid' should be included in the plans for the next quinquennium. Only in this way can the gross shortage of acoustical and vibration engineers be met.

Such a step is not an unnatural one. Engineering has been defined as the efficient application of the sciences in the interests of the community. Thus a good engineering training, in addition to the teaching of the fundamental sciences and methods of application, also includes some training in economics and in the behaviour of the community. The engineer expects to be interested in 'human engineering', as it is called in the United. States, and not only in the purely scientific aspects of his work.

What steps should be taken if the above point of view is accepted ? The establishment at Southampton of a year's postgraduate M.Sc. course in 'vibration and noise studies' to commence in October, and the provision of a readership and lectureship by the Hawker Siddeley Group to support this course is ample evidence of my view. However, a case can also be made out for a 'human engineering' option in the undergraduate stage of the degree in engineering. Such a course could well provide tuition in acoustics, vibration and elementary physiology in the third year in the way that aerodynamies and design, nuclear power and thermodynamics, and hydraulics and soil mechanics is provided now for the aeronautical, nuclear and civil engineer respectively.

Bearing in mind the ever-present practice of putting more and more in a pint pot, the universities themselves favour specialization in the fourth year rather than at the undergraduate stage. However, the pressure from industry for the services of even mediocre students is putting the success of fourthyear M.Sc. courses in jeopardy, and it is to be hoped that industry and the research establishments will themselves see fit to sponsor for such courses students coming into their employ, in order to put right the complaint regarding training so often made at this excellent conference.

\title{
OBITUARIES
}

\section{Dr. Lee de Forest}

Dr. LeE DE Forest, a pioneer in the history of radio communications and, after much litigation, the acknowledged inventor of the three-electrode thermionic valve, died on June 30 in California at the age of eighty-seven. He was born in August 1873 in the parsonage at Council Bluffs, Iowa, his father being a Congregational minister in that town. Like his father, he graduated from the Yale Sheffield Scientific School in 1896, receiving his Ph.D. degree three years later. While at Yale his interest in electrical phenomena was stimulated by the work of Sir William Crookes and Nikola Tesla and by witnessing demonstrations of Hertz's experiments on electromagnetic waves. In 1899 he went to Chicago to work in the Dynamo Department of the Western Electric Co., and it was there that he became interested in the possibilities of a hot gas or flame detector as an alternative to the coherer then used in wireless receiving circuits.

From this he turned his attention to the Edison effect which he had learnt about at Yale, and which led J. A. Fleming to patent, in 1904, the first diode thermionic valve detector. Two years later, on October 25, 1906, de Forest applied for a patent for a three-electrode valve - a triode-as a device for 
amplifying weak alternating currents such as were obtained in the reception of radio signals. This was achieved by applying a voltage to the third electrode inserted between the hot filament or cathode, and the plate, or anode. A few months later, de Forest extended the patent to cover the use of the threeelectrode valve as a detector.

With a true inventor's imagination, Lee de Forest foresaw some of the possibilities of radio telephony and broadcasting; and, using an arc transmitter at the Metropolitan Opera House in January 1910, he was the first to broadcast opera arias sung by Caruso and other noted artists.

In 1914 the three-electrode valve was introduced as an oscillator and quickly replaced the are as a source of continuous oscillations for radiotelephony. It was during the First World War, with the great demands it made on radio communications, that the thermionic valve was rapidly developed and applied to the generation of electromagnetic waves at the sending station, and to the detection and amplification. of signal currents at both radio and audio frequencies at the receiver. During the period 1919-24, de Forest devoted most of his attention to the problems of talking cinematograph films, and his phonofilm was an early development in this field.

Altogether he held some 300 patents in the United States and other countries, covering such subjects as the guidance of aircraft by radio beams, the wire transmission of news pictures, and the measurement of cosmic rays. He was awarded the Cross of the French Legion of Honour, and his work was recognized in the United States by the receipt of the Edison Medal and Elliott Cresson Medal of the Franklin Institute, and by Gold Medals at the St. Louis Exhibition in 1904 and the Panama Pacific Exhibition in San Francisco in 1915. He was a founder, Fellow and past-president of the Institute of Radio Engineers (New York), the Gold Medal of which he won in 1922. Apart from various scientific papers, Lee de Forest was the author of Television Today and Tomorrow and his autobiography entitled Father of Radio.

R. L. SMrth-Rose

\section{Prof. B. Hague}

Prof. Bernard Hague died on September 29 , 1960 , in his sixty-eighth year, having occupied the James Watt chair of electrical engineering in the University of Glasgow since 1946, on the retirement of Prof. G. W. O. Howe. Born at Barnsley, Yorkshire, he received his early education at the Grammar School, Eccles, and at the Central School, Rochdale. $\mathrm{He}$ started as a millwright apprentice in Rochdale at the age of fifteen and later served as a junior draughtsman with Messrs. Ferranti, Ltd., Hollinwood. He attended evening classes at Rochdale Technical School from where he obtained an exhibition enabling him to study at the City and Guilds College, London. He graduated with first-class honours in 1915 , and in the following year obtained the diploma of the Imperial College of Science and Technology. During 1916-20 he was employed as a technical assistant at the Royal Aircraft Establishment, Farnborough, and he began his teaching career with an appointment as a lecturer at the City and Guilds College after being awarded an M.Sc. degree in 1919. His association with the late Prof. G. W. O. Howe, then a lecturer at the City and Guilds College, led to his appointment as a lecturer at the University of Glasgow in 1923, after the appointment of G. W. O. Howe to the James Watt chair of electrical engineering at that University in 1921 .

In 1926 he was awarded the Ph.D. of the University of Glasgow, and became a D.Sc. in 1927 and a Fellow of the City and Guilds of London Institute in 1936.

Prof. Hague was a true scholar of wide knowledge and experience. His intellectual pursuits and admir. able personal characteristics earned him the respect of many and the loyalty of his staff. He was the author of books on a.c. bridge methods, instrument transformers, electromagnetic problems in electrical engineering, an introduction to vector analysis and the method of symmetrical co-ordination in the theory of polyphase circuits. His A.C. Bridge Methods is still regarded as a reference text and has been translated into several languages.

Hague had a particular clarity of presentation both in his writing and in his teaching and this reflected a thoroughness and sincerity of personal endeavour. He appreciated the visual arts and had $a$ deep interest in music, being himself an oboist of distinction. He was a member of the Royal Musical Association and previously a governor of the Royal Scottish Academy of Music.

Above all, his interest in his students was personal and genuine, and he was ever ready to give of himself to the benefit of others, thereby gaining great respect and affection from all with whom he came into contact.
J. LAMrB

\section{NEWS and VIEWS}

\section{Chemical Defence Experimental Establishment, Porton : Dr. E. A. Perren}

Dr. E. A. Perren has just retired from the post of director of the Chemical Defence Experimental Establishment, Porton, after thirty-eight years service in the War Department and Ministry of Supply. He studied chemistry at the Royal College of Science and obtained his Ph.D. in 1922 for researches in Prof. Jocelyn Thorpe's laboratory on three-carbon tautomerism. He then continued to work with Thorpe, as his assistant, at Porton and was absorbed later into the permanent staff there. He was concerned for many years with research into methods of producing smoke-screens, and the results of this work were put to profitable use during the Second World War. His responsibilities afterwards widened and included spells of duty at headquarters and in supervisory work at the Establishment. During 1948-49 he returned to the laboratory to undertake some research in organic chemistry and was then loaned for two years to the Canadian Government to take charge of its Experimental Station at Suffield, Alberta. In 1955 he was appointed director at Porton and retires with the rank of chief scientific officer. Dr. Perren is to continue to serve the Chemical Defence Experimental Establishment in the research labor. atories. 